\title{
FOREIGN EXCHANGE RATE REGIMES AND FOREIGN EXCHANGE MARKETS IN TRANSITIVE ECONOMIES
}

\author{
Jaroslava Durčáková*
}

\begin{abstract}
:
In this paper we discuss the issue of the choice of foreign exchange rate regimes in transitive economies, their effect on the relative changes and the volatility of the foreign exchange rate and the development of the national foreign exchange market. The results of our analysis indicate that the choice of the foreign exchange rate regime is not a passive factor regarding both average relative changes in exchange rates and volatility as measured by the standard deviation. They also show that increased volatility of spot rates and a growing interest rate differential lead to the growth of the share of outright forwards and swaps (e.g. transactions that might be used for hedging) in relation to spot transactions.
\end{abstract}

Keywords: transitive economies, foreign exchange market, foreign exchange rate, foreign exchange rate regime.

JEL Classification: E310, F430

\section{Introduction}

The continuing process of transformation has created, in the transitive economies, conditions for starting, or renewing, the convertibility of their national currencies, as well as the development of a national foreign exchange market. One of the important elements of their monetary policy was the selection of a foreign exchange rate regime. The aim of this article is to judge whether there exists a connection between the choice of foreign exchange rate regime in the transitive economies, volatility of the exchange rate of the home currency and the development of the national foreign exchange market.

In the second part of this article we focus on the choice of FX regimes in selected transitive countries in connection with the volatility of their national currencies in the period of 1999-2009. In the third part, an attention will be given to the foreign exchange market. We attempt to answer the question of whether the choice of a foreign exchange rate regime influences the stability of the national foreign exchange market, or, conversely, whether it contributes to its instability. In the group of selected national currencies of the transitive economies we shall, on the basis of cross sectional analysis, examine the connection between the choice of a foreign exchange rate regime, and

* Universiy of Economics, Prague (durcakova@vse.cz).

The article was written with support from the Grant Agency of the CR within the framework of GACR P402/10/0289. 
daily average foreign exchange market turnover from the viewpoint of FX transactions (spot transactions, outright forwards and swaps). In the concluding part, we focus on the time series analysis of the foreign exchange market in the Czech Republic.

Because of the limited availability of the data necessary for the analysis, we concentrate on a group of 18 representatives of the transitive economies. Of the group of transitive economies, which are the subject of our research, only 13 are included in the available overview of the development of the foreign exchange market activity. For reasons of historical comparison, we include both countries which fulfilled the criteria stipulated by the European Bank for Reconstruction and Development for the identification of the transitive economies; and those countries which, by their accession to the EU, already completed their transformation during the period under examination.

\section{Choice of Foreign Exchange Rate Regime in the Transitive Economies in the Period 1999-2009}

The organization of foreign exchange relations within the framework of the foreign exchange rate regimes is linked, mainly, with the various tasks of the central banks (and other official monetary authorities) and the markets, when determining the exchange rates and with the different levels of preference for stability or flexibility of the rate. In this study we analyze the foreign exchange rates with regard to their flexibility. We call those fixed rates with a hard peg to another currency inflexible. This includes a currency board regime with an irrevocable central parity $(\mathrm{CP})$, and exchange rate arrangements with no separate legal tender. ${ }^{1}$ Less flexible fixed rates (soft peg) include the classic exchange rate regime of the fixed rate with narrow margins of fluctuation; a maximum to $+/-1 \%$ around a central parity, with irregular changes in central parity (for instance, a conventional fixed peg, or even a peg like arrangement as is, for instance, the regime of stabilized exchange rates). More flexible fixed rates (intermediate pegs) are fixed rates with wider margins of fluctuation, i.e., with a greater deviation than $+/-1 \%$ of central parity (e.g., within horizontal bands); crawling peg arrangements (without bands of fluctuation); and crawling bands (with limited bands of fluctuation). In both the latter cases, changes in central parity are, as a rule, announced by the central bank in advance. We include, in this study, other managed arrangements, into more flexible rates. Floating rates include both managed floating rates (until 2009: floating), and independent floating (from 2009: free floating). Development of the foreign exchange rate regimes of IMF member states in the period 1999-2009 is shown in the Graph 1.

1 Effectively in 2009, the IMF revised the classification of the foreign exchange rate regimes. For more detail see Habermeier, K., Kokenyne, A., Veyrune, R., Anderson, H. (2009). 


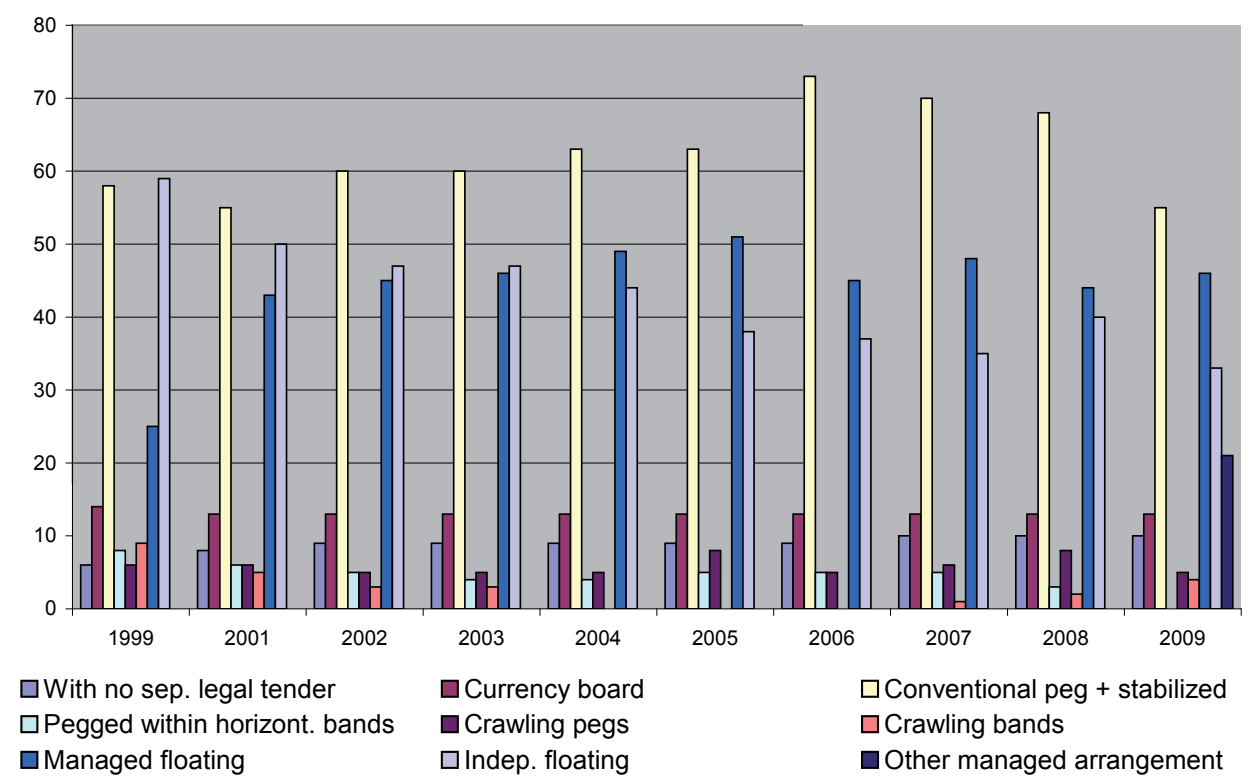

Source: De Facto Classification of Exchange Rate Regimes and Monetary Policy Frameworks 1999-2009

An important element of the qualitative characteristics of currencies is their convertibility. Of the total number of 187 IMF member states, in 2009, 166 countries (almost $89 \%$ of IMF member states) adopt convertibility of their national currency. Launching the convertibility of the national currencies of the transitive economies was one of the essential requirements for the development of their national foreign exchange markets. The transitive countries, which are the subject of our analysis, renewed the convertibility of their national currencies in the sense of Article VIII, Sections 2, 3 and 4 of the Articles of Agreement (IMF) in the period 1994-1998 (see Table 1).

Table 1

Members that Have Accepted the Obligation of Article VIII, Section 2, 3 and 4 of the Articles of Agreement

\begin{tabular}{|l|l|}
\hline Bulgaria & September 24, 1998 \\
\hline Czech Republic & October 1,1995 \\
\hline Estonia & August 15, 1994 \\
\hline Hungary & January 1,1996 \\
\hline Latvia & June 10, 1994 \\
\hline Lithuania & May 3, 1994 \\
\hline Macedonia & June 19, 1998 \\
\hline
\end{tabular}

\begin{tabular}{|l|l|}
\hline China & December 1,1996 \\
\hline Russian Federation & June 1, 1996 \\
\hline Slovak Republic & October 1, 1995 \\
\hline Slovenia & September 1, 1995 \\
\hline Thailand & May 4, 1990 \\
\hline Ukraine & September 24, 1996 \\
\hline
\end{tabular}

Source: IMF Annual Report Appendix 2009, IMF 2010 
Deciding which foreign exchange regime to use is one of the important elements of monetary policy. Regarding the choice of optimum exchange rate arrangement, there is a lot of literature in economic theor ${ }^{2}$ and practical recommendations from the $\mathrm{IMF}^{3}$ Usually, the following are considered:

a) Fundamental factors of macroeconomic development include:

- the structural characteristics of the economy, mainly the extent of price, wages and the production factors flexibility (namely; labour mobility), the degree of internal and external equilibrium;

- emerging macroeconomic conditions and the possibility to use other nominal anchors than the fixed rate (e.g., inflation targets inflation targeting framework or monetary aggregate) for stabilization purposes;

- the degree of openness of the economy in the area of foreign trade and international movements of capital;

- the amount and structure of the international reserves.

b) Institutional factors, fiscal and monetary policy:

- participation in regional groupings binding countries to certain economic policies and certain currency exchange regimes;

- the demanded degree of independence of monetary policy;

- the level of development of the financial/foreign exchange markets activity.

Economists still ask the question of whether the applied exchange rate regime plays any role at all from the viewpoint of macroeconomic environment development. Attention is devoted to the influence of the exchange regime on inflation and economic growth (Gosh-Ostry-Gulde-Wolf, 1997; Levy-Yevati and Sturzenegger, 2003; DuttaguptaFernandez-Karacadag, 2005, 2005; Atish R. Ghosh, Jonathan D. Ostry, 2009).

In this article we are trying to find an answer, mainly, to whether the foreign exchange rate regime choice influences equally the system of a functioning foreign exchange market. Fixed rates applied in the transitive economies usually limit the development of the foreign exchange market's activity. The market appears paralyzed from both the point of view of the application of knowledge, and the development of activity on the foreign exchange market. The fixed rate regime is linked to the prevalent spot transactions. Currency futures and options are added to the foreign exchange market later, as a rule together with the transformation to the exchange rate regime with relatively greater flexibility (fixed rates with wider oscillation bands and floating exchange rates, with either managed or independent floating). It is so for the following reasons:

- at the beginning of transformation there was, in the business sphere, a lack of knowledge about the foreign exchange market, its functioning and operation (foreign trade transactions before 1990 were exclusively carried out on the basis of the monopoly of foreign trade enjoyed by the specialized foreign trade firms); business subjects were just starting to gradually orient themselves in the transactions and instruments which could be useful for hedging;

2 See, e.g.: Fischer, S. (2001); Szapary, G. (2001); Gosh, A. R., Ostry, J. D., Gulde, A. M., Wolf, H. C. (1997); Brůna, K. (2007); Šaroch, S., Šindel, J. (2008); Mandel, M., Zelenka, V. (2010).

3 IMF World Outlook 1996. 
- a very narrow margin of fluctuation when using a fixed rate, substantially reduces foreign exchange exposure and exchange risk, the need to cover exchange risk does not appear very prominent;

- the change over to the exchange regime with the greater amount of flexibility increases the foreign exchange risk, and also demands the development of adequate foreign exchange transactions and instruments which serve to cover exchange risk.

Fixed rates reduce the foreign exchange exposure and risk. They are connected with the preference for stability and certainty. On the other hand, as for instance the Czech experience shows, nominal rates do not adjust to the inflationary differential; disequilibrium in the balance of payments is evened out by changes in the foreign exchange reserves, not by changes in the exchange rates.

Empirical experience (Durčáková, 2009), however, shows that the fixed rate itself does not guarantee exchange rate stability if the fixed rate does not reflect stability in the fundamental factors of the economy. A limited oscillation band, then, is not credible, and leads either to the expansion of the oscillation band, or to the devaluation of the currency, even to changes in the regime. On the other hand, even economies which use floating exchange rate regimes do not necessarily need a growth in inflation, or instability in other macroeconomic elements. They also do not have to create sufficient pre-conditions for the development of the national foreign exchange market and the corresponding variety of foreign exchange transactions, if the floating is only declared; de facto, however, the extent of its flexibility is mostly set by the intervention policy of the central bank.

\section{Exchange regimes examined in transitive economies and the volatility of their rates}

We follow the volatility of the foreign exchange rate in the preference of the various exchange regimes with different amounts of flexibility, in the group of countries which in the subsequent period fulfilled the criteria set by the European Bank for Reconstruction and Development (EBRD) for measuring development in transition. According to these criteria, the countries of Central and Eastern Europe are considered as transitive economies. The Asian economies, along with those of the countries of the Commonwealth of Independent States also belong under the term. The EBRD criteria include a host of integral indicators. They concern, namely, the privatization process, government and business restructuring and price liberalization. In addition, the foreign exchange rate regime, bank reform, securities market, interest liberalization and others are covered. ${ }^{4}$

With regard to the criteria set by the EBRD, we consider the economies of a total of 25 countries as transitive economies. ${ }^{5}$ On the other hand, the countries which joined the EU on 1 May, 2004 are considered as having already completed the process of

4 For more details, see Wikipedia, Transitive Economy, 2008

5 The group of Asian countries considered as transitive economies: China, Cambodia, Laos, Mongolia, Thailand and Vietnam. Of the group of Central and Eastern European countries with transitive economies are the following: Albania, Bosnia and Herzegovina, Croatia, Macedonia, Montenegro and Serbia. The third group of transitive economies consists of the countries of the Commonwealth of Independent States: Armenia, Azerbaijan, Belorussia, Georgia, Kazakhstan, Kyrgyzstan, Moldavia, Russia, Tadzhikistan, Turkmenistan, Ukraine and Uzbekistan. 
transformation of their economies. ${ }^{6}$ As regards the availability of the data necessary for our analysis, we focus on 18 representatives. For reasons of historical comparison there are included both countries which, during the period under examination, had already completed their transformation by joining the EU (CR, Bulgaria, Hungary, Poland, Romania, Slovakia and Slovenia), and those which are, to date, still considered to be transitive economies (China and Thailand, Croatia, Estonia, Latvia, Lithuania and Macedonia, as well as Armenia, Moldavia, Russia and Ukraine). In the transitive economies under examination, all four categories of exchange regimes which were presented in the classification of exchange rate arrangements are used in this paper.

Bulgaria, Estonia and Lithuania belongs to the group with fixed inflexible rates. These countries, during the whole period under examination, have applied the currency board pegged to the euro. The basic element of this rigid regime is the irrevocable obligation of the central bank to maintain fixed rates of its currency to the reference currency, without the possibility of devaluation or revaluation. The central bank surrenders almost all its instruments of control with an exception of non-sterilized foreign exchange intervention. The theoretical basis of the currency board regime comes from the monetarist approach to the balance of payments, which considers disequilibrium in the supply of, and demand for, money to be the cause of disequilibrium in the balance of payments. According to this approach, the dominance of money supply leads to deficit disequilibrium in the balance of payments. Conversely, when the demand for money is greater than the supply, then, there is a surplus disequilibrium in the balance of payments. Non-sterilized foreign exchange intervention represents a self-regulatory mechanism, which constantly brings the supply and demand for money into harmony. The currency board is usually considered to be advantageous in countries which suffer from deep disequilibrium of an inflationary character, and where there is a threat that the national currency will be pushed out of circulation by some of the more stable world currencies. ${ }^{7}$

Latvia, China, Macedonia and Ukraine employed during the examined period the exchange rate regime with lesser flexibility, that is, the exchange regime with a narrow oscillation band, where the rate can move in the margin of $+/-1 \%$ of central parity. ${ }^{8}$

In the case of Macedonia, this classical regime of fixed rates was used during the entire course of the examined period. China and Latvia maintained the exchange regime with lesser flexibility as their prevalent regime. China kept the fixed rates with the narrow oscillation band for its currency. The yuan (also called the renminbi) was pegged to the USD from 1995 to July, 2005. In July, 2005 China announced the revaluation of the yuan by $2.1 \%$, and at the same time decided to peg the parity of its currency to a currency basket. However, because the yuan parity fluctuations did not exceed, by July, 2006, an overall limit of $2 \%$, the IMF, in 2006, classified China as a country which de facto uses a fixed rate with a narrow oscillation band. In 2007 there

\footnotetext{
6 They are the following countries: CR, Estonia, Hungary, Latvia, Lithuania, Poland, Slovakia and Slovenia.

7 Questions on the practical uses of the currency board regime; see, e.g., Singal, Vijay (1999),

8 Considerations of the pro's and cons of fixed and floating rates have been the subject of a lot of publications; e.g., Friedman (1953), Johnson (1973, 1976), Crockett (1976), Fleming (1975), Keller (1978), Jonas (1995), Azir, Caramazza (1998).
} 
were changes made in the application of the exchange rate regime towards greater flexibility and China implemented the crawling peg - pegged to the USD. Ukraine has been using the above mentioned regime of fixed rate with a narrow oscillation band since 2003.

Only Hungary has maintained, for the whole of the examined period, fixed rates with greater flexibility and kept to an oscillation band of $+/-15 \%$ for the changes of the forint to the euro. From 25th February, 2008, the forint came onto the regime of floating exchange rates. In light of the fact that none of the other countries in the group uses the exchange rate regime with greater flexibility, we shall place Hungary into the floating rates category in the following analysis.

Relatively speaking, the biggest group in the transitive economies under our analysis consists of countries which apply floating rates. This comprises the following 10 countries: CR, Croatia, Poland, Romania, Russia, Slovenia, Thailand, Slovakia, Moldavia and Armenia. Most countries covered by our analysis have been using the chosen exchange rate regime, either for the whole of the examined period, or as the clearly pre-dominant regime.

In the following empirical analysis, we depend on the development of the nominally effective exchange rates (neer). The hypothesis appears to be that countries with fixed exchange rate should have lower average relative changes in neer, and at the same time, even lower volatility of neer. In Table 2 we can follow the average relative changes in neer and the values of standard deviations of neer for the period 1999-2009 (quarterly frequency) and that is both in individual countries and two groupings;-fixed and floating exchange rates. We include in the first group of fixed rates both fixed rates with irrevocable central parity and fixed rates with a flexibility of a maximum of $+/-1 \%$ parity, thus, the lesser degree of flexibility. In the second group, we follow countries which give preference to floating rates, with a greater degree of flexibility. As has been mentioned above, Ukraine has not been included in the analysis for reasons lack of uniformity in the pre-dominant exchange regime used in the period under examination.

Table 2

Relative Changes and Volatility of Nominal Effective Exchange Rates in Fixed and Floating Regimes

\begin{tabular}{|l|c|c|c|c|c|c|c|}
\hline \multirow{2}{*}{$\begin{array}{l}\text { Relative } \\
\text { changes }\end{array}$} & \multicolumn{7}{|c|}{ Countries with fixed foreign exchange rate regimes } \\
\cline { 2 - 8 } & Bulgaria & Estonia & Lithuania & Latvia & China & Macedonia & Average \\
\hline $\boldsymbol{\varnothing}$ neer & 0.37 & 0.22 & 0.86 & -0.16 & 0.02 & 0.68 & $\mathbf{0 . 3 8 5}$ \\
\hline $\boldsymbol{\delta}$ neer & 1.37 & 1.35 & 1.90 & 1.74 & 1.94 & 1.04 & $\mathbf{1 . 5 6}$ \\
\hline
\end{tabular}

Note: Fixed rates in this case include: inflexible fixed rates (currency boards) and rates with limited flexibility (with an fluctuation of $+/-1 \%$, max.) without Ukraine. 
Table 2 - Continuation

\begin{tabular}{|c|c|c|c|c|c|c|c|c|c|c|c|c|}
\hline \multirow[b]{2}{*}{$\begin{array}{l}\text { Relative } \\
\text { changes }\end{array}$} & \multicolumn{12}{|c|}{ Countries with floating foreign exchange rate regimes } \\
\hline & 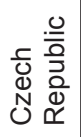 & $\begin{array}{l}\stackrel{\frac{\pi}{ \pm}}{\pi} \\
\stackrel{0}{0} \\
\text { U. }\end{array}$ & $\begin{array}{l}\frac{0}{0} \\
\frac{\mathbb{\pi}}{0} \\
0\end{array}$ & 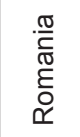 & $\begin{array}{l}\frac{\pi}{\infty} \\
\stackrel{0}{D} \\
\vec{x}\end{array}$ & $\begin{array}{l}\frac{\sigma}{\frac{\sigma}{\sigma}} \\
\frac{\partial}{\omega}\end{array}$ & 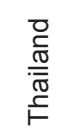 & 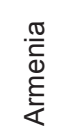 & $\begin{array}{l}\frac{\pi}{\frac{\pi}{\sigma}} \\
\frac{\partial}{\omega}\end{array}$ & $\begin{array}{l}\frac{\pi}{2} \\
\frac{\pi}{0} \\
\frac{0}{2}\end{array}$ & $\begin{array}{l}\frac{2}{0} \\
\stackrel{0}{0} \\
\stackrel{5}{1} \\
\text { Tे }\end{array}$ & $\begin{array}{l}\stackrel{0}{0} \\
\frac{\pi}{0} \\
\frac{\pi}{2}\end{array}$ \\
\hline$\varnothing$ neer & 1.26 & 0.30 & 0.76 & -2.02 & -0.51 & -0.51 & 0.01 & 1.40 & 0.93 & -0.77 & 0.24 & 0.792 \\
\hline$\delta$ neer & 2.38 & 1.37 & 4.28 & 0.08 & 2.39 & 1.29 & 2.71 & 3.20 & 2.28 & 3.98 & 2.79 & 2.80 \\
\hline
\end{tabular}

Note: Floating rates in this case include even rates with greater flexibility (Hungary; fixed rates with a band of $+/-15 \%$ ).

Average absolute changes in neer in regimes of fixed rates achieved values of 0.39 , in regimes of floating rates, then, according to expectation, they reached higher values of 0.79 . The average standard deviation of neer in regimes of fixed rates came to values of 1.56. In the group of countries with floating rates, then, as we presumed, values were higher - the average direction-giving deviation achieved values of 2.80 . Our results, therefore, show that the choice of fixed rates to one of the chosen leading currencies shows, on average, greater stability in exchange rates towards the group of currencies contained in neer because both criteria are in tune with the hypothesis that fixed rates have lower averages, both in relative change of exchange rates and in their volatility measured by the standard deviation.

\section{The Development of the Foreign Exchange Markets in Selected Transitive Economies}

In the period 1998-2010, the global foreign exchange market daily turnover, expressed in USD, increased 2.61 times. $^{9}$

9 BIS has presented a survey of the development of the foreign exchange market turnover since 1986. Comparison of data in time is, however, problematic for several reasons. The numbers of countries which are included in the BIS overview have, during past years, changed substantially. Whilst in the first triennial in 1986, only 4 countries [Canada, Japan, the United Kingdom and the USA] participated; three years later a further 17 countries were included in the overview of data on the foreign exchange markets. In 1992 the number of countries grew to 26; in 1995 the number of participating countries did not change, but substantial changes took place in 1998, when, in the triennial, another 17 countries took part. Among them, for the first time, there also appeared some of the transitive economies: China, the Czech Republic, Hungary, Poland, Russia and Thailand. In 2001, the overview of the dynamics of turnover on the foreign exchange markets expanded by another 17 countries, among them were Slovenia and Slovakia. In 2004 it grew to include Estonia, Latvia and Lithuania. In 2007, when there was published the then latest overview of the foreign exchange market, it included a total of 54 countries. Bulgaria and Romania were also invited to take part. In the BIS information from 2007 on the development of the foreign exchange market on the global scale and specific geographical divisions, there are included a total of 13 transitive economies. The changing participation of the number of included countries is not the only reason why it is not possible to compare the published data in time, but only divided into individual time periods. 


\section{Graph 2}

Global Foreign Exchange Market Turnover according to the Type of Foreign Exchange Transaction (in billions of USD, 1998-2010)

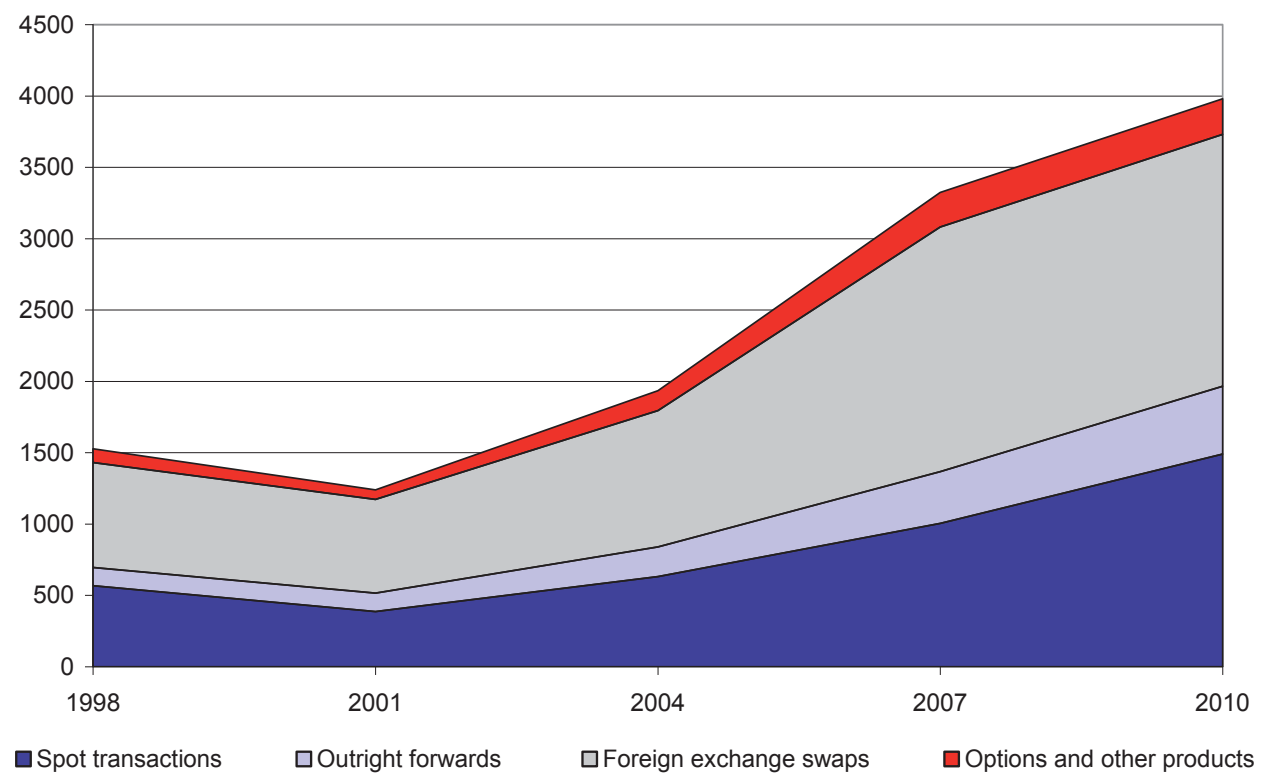

Source: BIS 2010.

In comparing data on the foreign exchange market turnover, expressed in USD, in time there appears a problem of changes in the USD rates with other currencies. Long-term depreciation of the USD in the period under examination has increased, after calculating in dollars, the volume of foreign exchange deals denominated in other national currencies. The rate of depreciation of the dollar in the period from one reporting date to the other (data are published at three year intervals) could, therefore, substantially influence the aggregate data. In order to eliminate, to a certain extent, this influence, historical exchange rates were substituted by the average rates from April 2007 in the BIS overview. To provide some guidance on the impact of actual exchange rate movements on total reported aggregates, pre-2010 totals have been provided additionally recalculated at constant exchange rates, replacing historical exchange rates by average April 2010 exchange rates. ${ }^{10}$

Cross sectional analysis of the relationships between the foreign exchange rate regime, its volatility and the development of the foreign exchange market.

Of the group of 18 analyzed transitive economies, only 13 have been included in the BIS overview of the development of the foreign exchange market on a global scale. Their average daily turnover on the national markets of the individual countries is 
illustrated in Table 3. These 13 economies account for only $0.8 \%$ (1998) - max. $2.3 \%$ (2007) of a share of the global daily average FX market turnover.

Table 3

Foreign Exchange Market Turnover Reported in Selected Transitive Economies (daily turnover in April, in USD billion and \%)

\begin{tabular}{|c|c|c|c|c|c|c|c|c|c|c|}
\hline & \multicolumn{2}{|c|}{1998} & \multicolumn{2}{|c|}{2001} & \multicolumn{2}{|c|}{2004} & \multicolumn{2}{|c|}{2007} & \multicolumn{2}{|c|}{2010} \\
\hline & Amount & $\%$ share & Amount & $\%$ share & Amount & $\%$ share & Amount & $\%$ share & Amount & $\%$ share \\
\hline Bulgaria & $\ldots$ & $\ldots$ & $\ldots$ & $\ldots$ & $\ldots$ & $\ldots$ & 0.5 & 0 & 0.9 & 0 \\
\hline Estonia & $\ldots$ & $\ldots$ & $\ldots$ & $\ldots$ & 0 & 0 & 1.3 & 0 & 1.1 & 0 \\
\hline Lithuania & $\ldots$ & $\ldots$ & $\ldots$ & $\ldots$ & 1 & 0 & 1 & 0 & 1.2 & 0 \\
\hline Latvia & $\ldots$ & $\ldots$ & $\ldots$ & $\ldots$ & 2 & 0.1 & 2.6 & 0.1 & 2.2 & 0 \\
\hline China & 0.2 & 0 & 0 & 0 & 0.6 & 0 & 9.3 & 0.2 & 19.8 & 0.4 \\
\hline $\begin{array}{l}\text { Czech } \\
\text { Republic }\end{array}$ & 5.1 & 0.2 & 2.1 & 0.1 & 2.4 & 0.1 & 5 & 0.1 & 5.1 & 0.1 \\
\hline Hungary & 1.4 & 0.1 & 0.6 & 0 & 2.8 & 0.1 & 6.9 & 0.2 & 4.2 & 0.1 \\
\hline Poland & 2.7 & 0.1 & 5.1 & 0.3 & 6.5 & 0.3 & 9.2 & 0.2 & 7.8 & 0.2 \\
\hline Romania & $\ldots$ & $\ldots$ & $\ldots$ & $\ldots$ & $\ldots$ & $\ldots$ & 2.5 & 0.1 & 3.2 & 0.1 \\
\hline Russia & 6.9 & 0.3 & 9.6 & 0.6 & 29.8 & 1.1 & 50.2 & 1.2 & 41.7 & 0.8 \\
\hline Slovakia & ... & $\ldots$ & 0.8 & 0 & 1.6 & 0.1 & 3.5 & 0.1 & 0.4 & 0 \\
\hline Slovenia & $\ldots$ & $\ldots$ & 0.1 & 0 & 0.1 & 0 & 0.3 & 0 & $\ldots$ & ... \\
\hline Thailand & 3.1 & 0.1 & 1.9 & 0.1 & 3.1 & 0.1 & 6.3 & 0.1 & 7.4 & 0.1 \\
\hline $\begin{array}{l}\text { Emerging } \\
\text { countries } \\
\text { (13) }\end{array}$ & 19.4 & 0.8 & 20.2 & 1.1 & 49.9 & 1.9 & 97.4 & 2.3 & 94.8 & 1.8 \\
\hline Total & 2099.40 & 100 & 1691.7 & 100 & 2608.50 & 100 & 4281.10 & 100 & 5056.40 & 100 \\
\hline
\end{tabular}

Source: BIS 2010.

Table 3 shows that in the countries in which currency boards are used (Bulgaria, Estonia and Lithuania), the national foreign exchange markets are, in the examined period, very little developed; the average daily turnover reaches maximum USD 1.3 billion (in Estonia in 2007; in Bulgaria and Lithuania even less). From the point of view of the percentage share, this range is so low that in BIS statistics it is shown as zero. In all the observed economies there can be seen a remarkable growth in the foreign exchange turnover in 2007, which corresponds to global developments. The percentage growth in comparison with 2004 is, however, in the countries under observation, varied. ${ }^{11}$ As Table 4 shows, only 6 of the 13 countries presented have

11 The Polish Central Bank, for instance, states that when using the ordinary(current) exchange rates PLZ/USD, turnover on the Polish foreign exchange market grew by $39 \%$ (i.e. USD 8.813 billion) in 2007. When we eliminate the appreciation of the zloty, and use historical exchange rates, the growth of the foreign exchange turnover in Poland comes to $18 \%$. In Denmark, for example, the growth of daily turnover on the foreign exchange market was higher in 2007 than at any time before that. The foreign exchange turnover on the Danish market showed even greater growth than that on the global scale. Against 2004, it grew by $111 \%$ (it came to USD 86 billion). If we eliminate the influence of the swinging exchange rates of the dollar, however, turnover growth on the Danish market was lower; it "only" reached $96 \%$. 
a national currency whose share of the global average daily foreign exchange turnover reached at least 1\% (ruble, zloty, renminbi, forint, Czech koruna and the baht). These currencies are independently monitored; Slovenia has been using the euro since 2007; Slovakia adopted the euro in 2009. The other currencies are covered in the column 'other currencies of the emerging economies'. We shall refer to the sectional analysis when examining the volatility of the exchange rates and the foreign exchange markets in this group of currencies. Fixed rates with narrow oscillation bands are maintained by the Chinese renminbi, Hungarian forint, afterwards, fixed rates with wider oscillation bands $(+/-15 \%)$ with pegging on the euro, for the whole of the period under examination. The other currencies gave preference to floating rates for the whole of the period under examination. Hypothetically, we shall assume that the higher volatility of exchange rates is linked with the higher amount of exchange rate risk. In the next part of this article we shall, therefore, see whether the higher volatility observed in currencies which give preference to floating exchange rates leads to differing structures of traded instruments on the foreign exchange markets.

Table 4

Currency Distribution of Global Foreign Exchange Turnover in Selected Transitive Economies (\% shares of average daily turnover in April)

\begin{tabular}{|l|r|r|r|r|r|c|}
\hline Currency & $\mathbf{2 0 0 1}$ & $\mathbf{2 0 0 4}$ & $\mathbf{2 0 0 7}$ & $\mathbf{2 0 1 0}$ & Volatility & Regime \\
\hline Russian ruble & 0.34 & 0.73 & \multicolumn{1}{|c|}{0.81} & 0.9 & 2.39 & floating \\
\hline Polish zloty & 0.56 & 0.53 & 0.79 & 0.8 & 2.39 & floating \\
\hline Chinese renminbi & 0.01 & 0.1 & 0.47 & 0.1 & 4.28 & fixed \\
\hline Hungarian forint & 0.02 & 0.22 & 0.28 & 0.4 & 2.79 & fixed \\
\hline Czech koruna & 0.3 & 0.2 & 0.22 & 0.3 & 2.38 & floating \\
\hline Thai baht & 0.19 & 0.23 & 0.21 & 0.2 & 2.71 & floating \\
\hline Slovak koruna & 0.04 & 0.06 & 0.1 & $\ldots$ & 2.28 & floating \\
\hline Romanian lei & - & - & 0.04 & - & 4.08 & floating \\
\hline Lithuanian litas & - & 0.01 & 0.02 & - & 1.90 & fixed \\
\hline Estonian kroon & - & 0 & 0.02 & - & 1.35 & fixed \\
\hline Latvian lats & 0 & 0 & 0.01 & - & 1.74 & fixed \\
\hline Bulgarian lev & 0 & 0 & 0.01 & - & 1.37 & fixed \\
\hline Emerging market currencies & 16.9 & 15.4 & 19.8 & - & & $\ldots$ \\
\hline
\end{tabular}

Source: BIS 2007, 2010 preliminary results.

Our second hypothesis states that: "The higher rate of foreign exchange rate risk connected with higher volatility of the exchange rate, also causes the growth of hedging and speculative transactions on the foreign exchange markets, and in consequence, this preference for floating rates leads to a growth in forward and swap transactions". 
Graph 3

FX Turnover by Currency and Instrument in April 2007 (\% share)

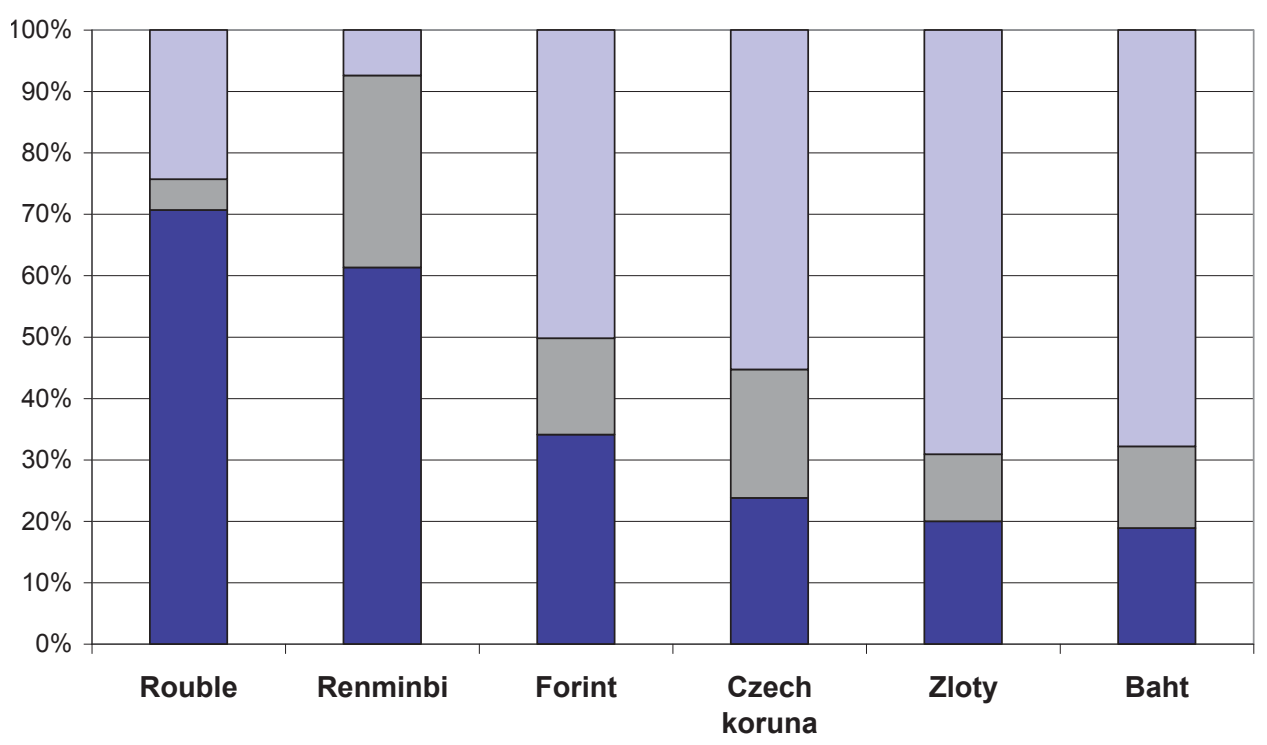

$\square$ Spot $\square$ Outright forwards $\square$ Foreign exchange swaps

Source: According to BIS 2010.

Graph 3 shows the structure of foreign exchange turnover according to the character of the foreign exchange transactions in 6 currencies, whose volume and share of the total foreign exchange turnover on the global scale is so significant that it is followed, and reported upon independently by the BIS; unlike other currencies of transitive economies, which are reported as a part of the section: "emerging market currencies". The high share of spot transactions comes from the currencies maintaining fixed rate regimes. In the case of the renminbi, the share of spot transactions is $61.4 \%$, in the forint case it is $34.1 \%$. The renminbi displays the highest volatility on neer during the period under examination. The ruble has the greatest amount of spot transactions $(70 \%)$ on its foreign exchange turnover. According to the IMF, Russia, at the same time, gives preference to the floating rates regime (in the period under examination; 1999-2007, the IMF included Russia amongst the countries preferring managed floating). In 2008 Russia returned to the fixed rate regime with the narrow oscillation band; from 2009, the exchange rate of the ruble was placed by the IMF among the "other managed exchange rate arrangement" regime. During the course of the interval observed, Russia showed a volatility of $2.39 \%$. In other currencies the share of spot transactions moves at around $18.9 \%$ (Thailand) $-20.3 \%(\mathrm{CR})$.

We have analyzed, in detail, the foreign exchange market in Russia based on information from the National Bank of the Russian Federation, in the 2003-2009 periods. We can see in Graph 4 the increased growth of spot transactions, namely between 2006-2008. In 2008, the daily turnover in spot transactions was 5.4 times 
higher than in 2003. In 2009, the turnover in spot transactions decreased to 3.17 times the turnover in 2003.
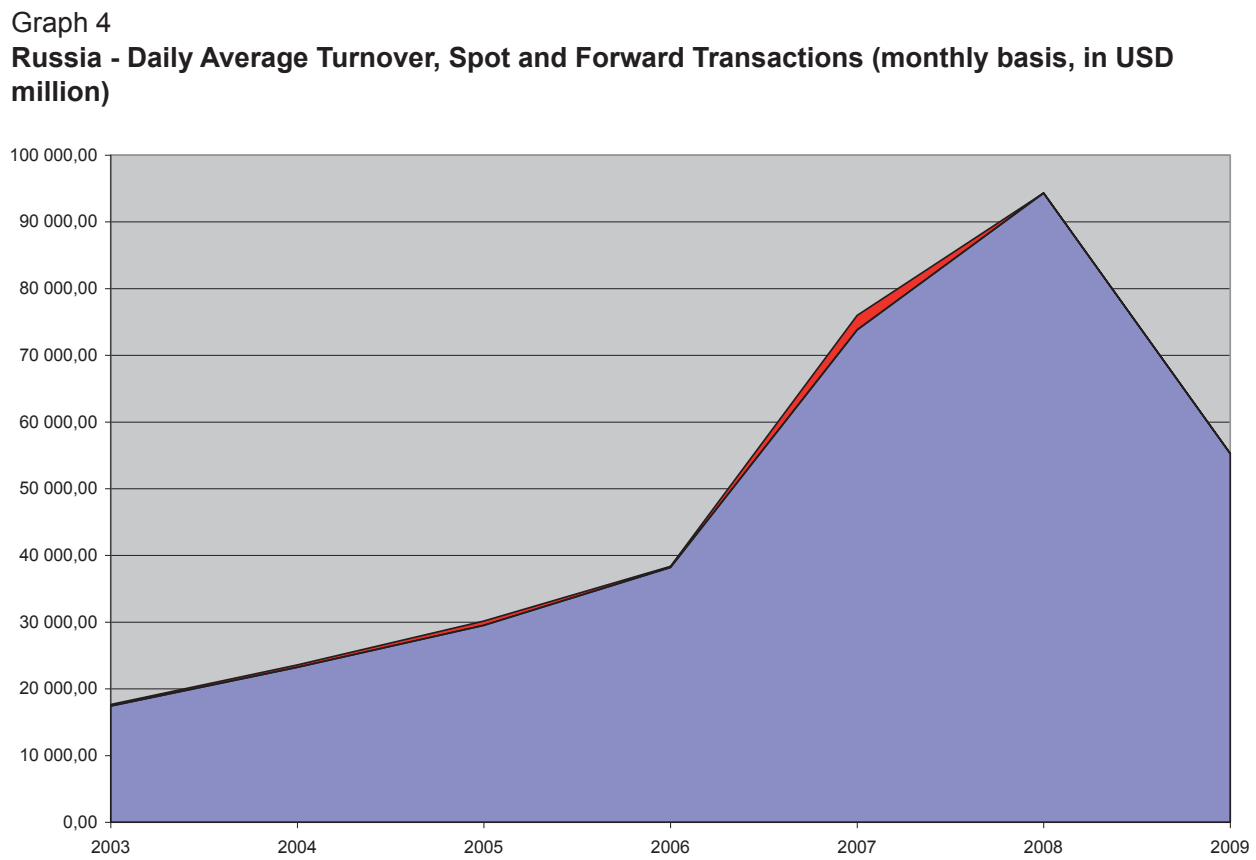

$\square$ Spot $\square$ Forward

Source: Bank of Russia, 2003-2009.

It may be assumed that the high share of spot transactions on the Russian foreign exchange market is influenced, mainly, by the following two factors:

1) The development of the nominal effective exchange rate of the rubble (NEER) emerges in the long period (1999-2009) of fairly marked stability; the relative change in NEER comes, in the period under examination, to 0.51 and the volatility of NEER is expressed as a standard deviation of 2.39 , which is less than that of the average currencies on the floating rate regime, and the rates with greater flexibility were included in the monitored group (2.80). The development of the nominally effective exchange rate of the ruble moved between $95-105 \%$ during the interval January 2003 - December 2008. 


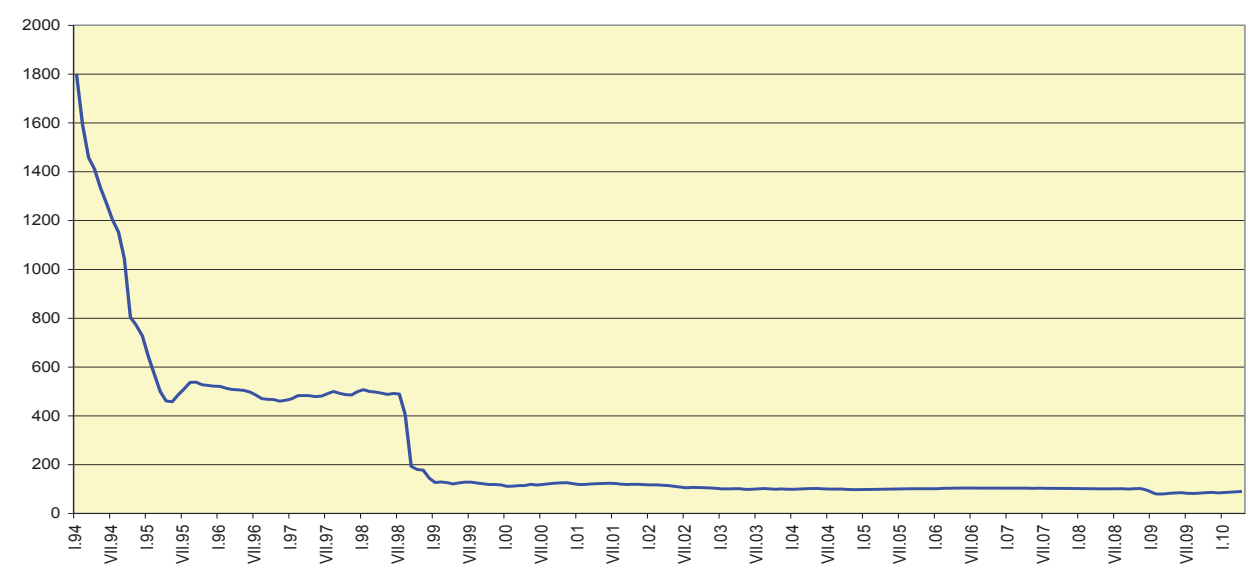

- Russia NBRU

Source: BIS 2010

The IMF includes Russia, in the period 1999-2007, amongst those countries that apply the floating rate regime (managed floating). In reality, the ruble is maintained from February 2005 as a fixed rate pegged to the currency basket, which consists of two currencies: the USD and the Euro. The weight of both currencies in the basket has changed several times. That can be seen in Table 5 .

Table 5

Weight of the USD and the EUR in the Ruble's Currency Basket from 2005

\begin{tabular}{|l|c|}
\hline Period & Monetary basket \\
\hline 8 February 2007 - & 0.55 USD / 0.45 EURO \\
\hline 1 December 2005 - 7 February 2007 & 0.60 USD / 0.40 EURO \\
\hline 1 August 2005 - 30 November 2005 & 0.65 USD / 0.35 EURO \\
\hline 16 May 2005 - 31 July 2005 & 0.70 USD / 0.30 EURO \\
\hline 15 March 2005 - 15 May 2005 & 0.80 USD / 0.20 EURO \\
\hline 1 February 2005 - 14 March 2005 & 0.90 USD / 0.10 EURO \\
\hline
\end{tabular}

The ruble's exchange rate, during the period under observation, is maintained in the desired corridor with the help of intervention by the central bank (see Table 6). 
Table 6

Data on the Bank of Russia Currency Intervention 8 /2008 - 4/2010

\begin{tabular}{|l|c|c|c|c|}
\hline \multirow{2}{*}{ Period of report } & \multicolumn{2}{|c|}{$\begin{array}{c}\text { The Bank of Russia USD dollar } \\
\text { transactions }\end{array}$} & \multicolumn{2}{c|}{$\begin{array}{c}\text { The Bank of Russia euro } \\
\text { transactions }\end{array}$} \\
\cline { 2 - 5 } & \multicolumn{2}{|c|}{ In USD million } & \multicolumn{2}{c|}{ In EUR million } \\
\cline { 2 - 5 } & $\begin{array}{c}\text { Total amount, } \\
\text { net purchases }\end{array}$ & $\begin{array}{c}\text { Regular } \\
\text { purchases }\end{array}$ & $\begin{array}{c}\text { Total amount, } \\
\text { net purchases }\end{array}$ & $\begin{array}{c}\text { Regular } \\
\text { purchases }\end{array}$ \\
\hline August 2008 & -30.98 & $6,513.27$ & 614.10 & 636.10 \\
\hline September 2008 & $-17,200.45$ & 558.55 & -492.23 & 64.65 \\
\hline October 2008 & $-38,552.49$ & 110.52 & $-3,431.45$ & 0.00 \\
\hline November 2008 & $-30,130.82$ & 0.00 & $-2,893.22$ & 0.00 \\
\hline December 2008 & $-57,414.22$ & 0.00 & $-12,633.57$ & 0.00 \\
\hline January 2009 & $-34,161.67$ & $3,561.09$ & $-4,087.27$ & 26.50 \\
\hline February 2009 & 861.80 & 0.00 & 98.97 & 0.00 \\
\hline March 2009 & $3,579.57$ & 0.00 & 189.94 & 0.00 \\
\hline April 2009 & $8,166.17$ & 0.00 & 331.44 & 0.00 \\
\hline May 2009 & $18,570.34$ & 0.00 & 449.27 & 0.00 \\
\hline June 2009 & $1,537.80$ & 0.00 & 48.06 & 0.00 \\
\hline July 2009 & $-3,093.77$ & 0.00 & -576.72 & 0.00 \\
\hline August 2009 & $-1,156.22$ & 0.00 & -177.76 & 0.00 \\
\hline September 2009 & $2,650.01$ & 250.00 & -39.12 & 0.00 \\
\hline October 2009 & $15,219.81$ & $2,386.58$ & 484.55 & 177.68 \\
\hline November 2009 & $7,316.88$ & $2,898.33$ & 745.14 & 641.01 \\
\hline December 2009 & 601.79 & $1,013.57$ & 240.68 & 240.68 \\
\hline January 2010 & $1,582.42$ & $1,582.42$ & 462.50 & 462.50 \\
\hline February 2010 & $6,703.82$ & $2,631.62$ & 302.03 & 159.22 \\
\hline March 2010 & $14,483.51$ & $3,064.99$ & 442.91 & 173.81 \\
\hline April 2010 & $11,336.70$ & $4,172.65$ & 411.84 & 169.65 \\
\hline
\end{tabular}

Source: Bank of Russia, 2010.

The structure of the foreign exchange transactions on the Russian national foreign exchange market confirms that in conditions of relatively stable development of the nominally effective exchange rates of the domestic currency, there does not arise any urgent need to develop foreign exchange transactions to minimize exchange risk, such as, for instance, forward and swap transactions. In addition, businesses do not use hedging transactions on the foreign exchange market for covering exchange risk.

2) Another factor which explains the decisive share of spot transactions on the overall average daily turnover on the Russian national foreign exchange market is the connection between the development of the ruble's exchange rate to the USD and the development of the dollar price per barrel of Ural oil. Oil, together with petroleum products and natural gas make up a large part of Russia's exports. According to data from the National Bank of Russia, these products, in 1999, accounted for $49.97 \%$ of 
total exports; in 2009, they made up 62.86\%. Exports of oil itself, in 1999, made up almost $19 \%$ of all exports; in 2009, it came to $33.16 \%$. Taken both from the price and exchange risk perspective, the total market risk is relatively low thanks to the negative values of the correlation coefficients between the development of the exchange rate of the ruble to the USD, and the development of the price of Ural oil per barrel in USD. This correlation coefficient makes up -0.62 (in the period 1/2006 - 4/2010, 52 comparisons). Graph 6 shows that independently covered foreign exchange risk with the help of foreign exchange transactions as forwards, would lead to an increase of the overall market risk, because the price risk remains uncovered.

\section{Graph 6}

Development of Exchange Rate RUB/USD and Price of Oil (2006 - 4/2010)

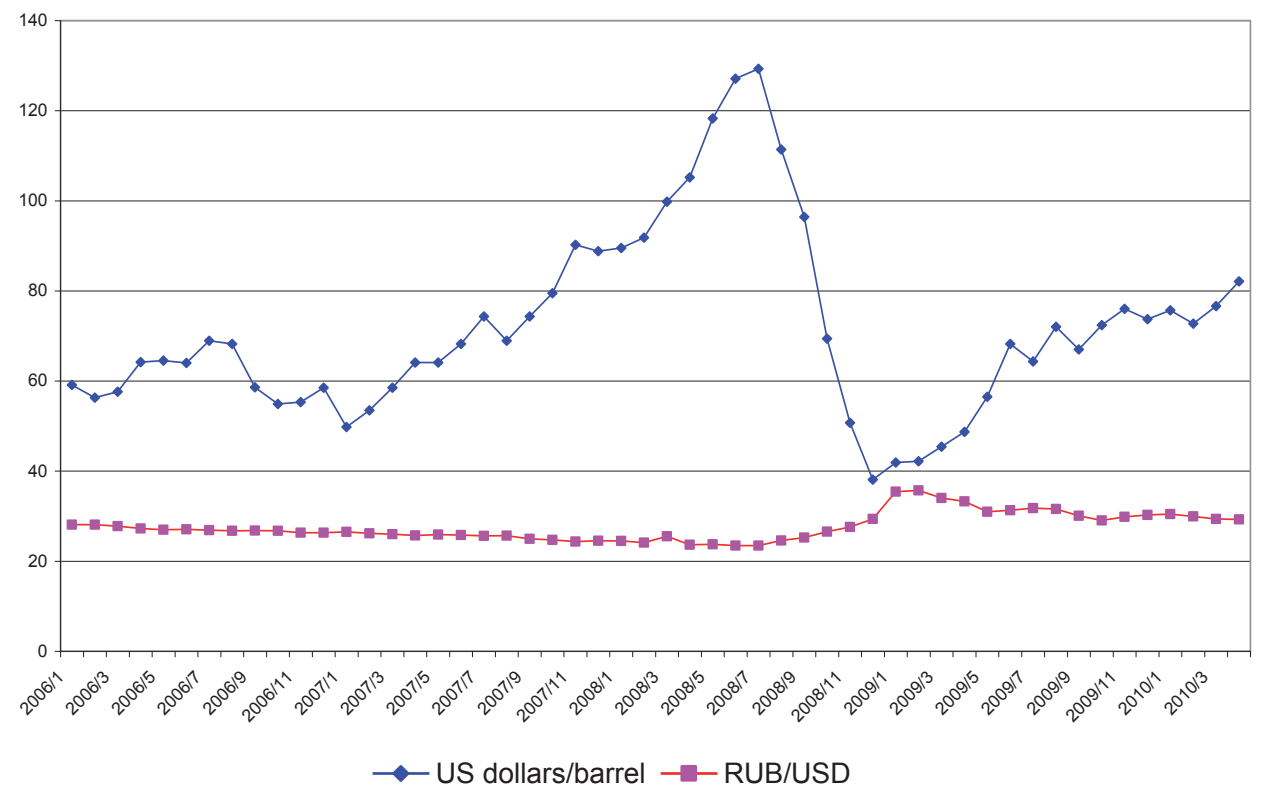

\section{Time Series Analysis of the Relationship between the Applied Regime of Foreign Exchange Rates, Volatility of the Exchange Rate of the Czech Koruna and the Development of the Czech Foreign Exchange Market}

The objective of our time series analysis is to test, on the example of the transitive economies, the hypothesis that the increased market risk, and increased values of the interest differential, lead to a growth in turnover on the foreign exchange market, namely, in the area of term foreign exchange transactions (forward, swap and options). We measure market risk with the aid of standard deviations on the basis of relative changes in the spot rates. The influence of the interest differential we monitor both on the basis of real interest differentials and the absolute values of the interest differential. Turnover on the foreign exchange market is then monitored on the basis of relative changes of the activity on foreign exchange market and the indicator of relations in the share turnover of forward and swap transactions and options on the spot turnover. 
Since in our group of observed countries, the available figures over the longer term are published only by the Czech National Bank, it was possible to test this hypothesis only on the domestic foreign exchange market.

\section{Graph 7}

\section{Average Daily Turnover on the Czech Foreign Exchange Market 1995-2010}

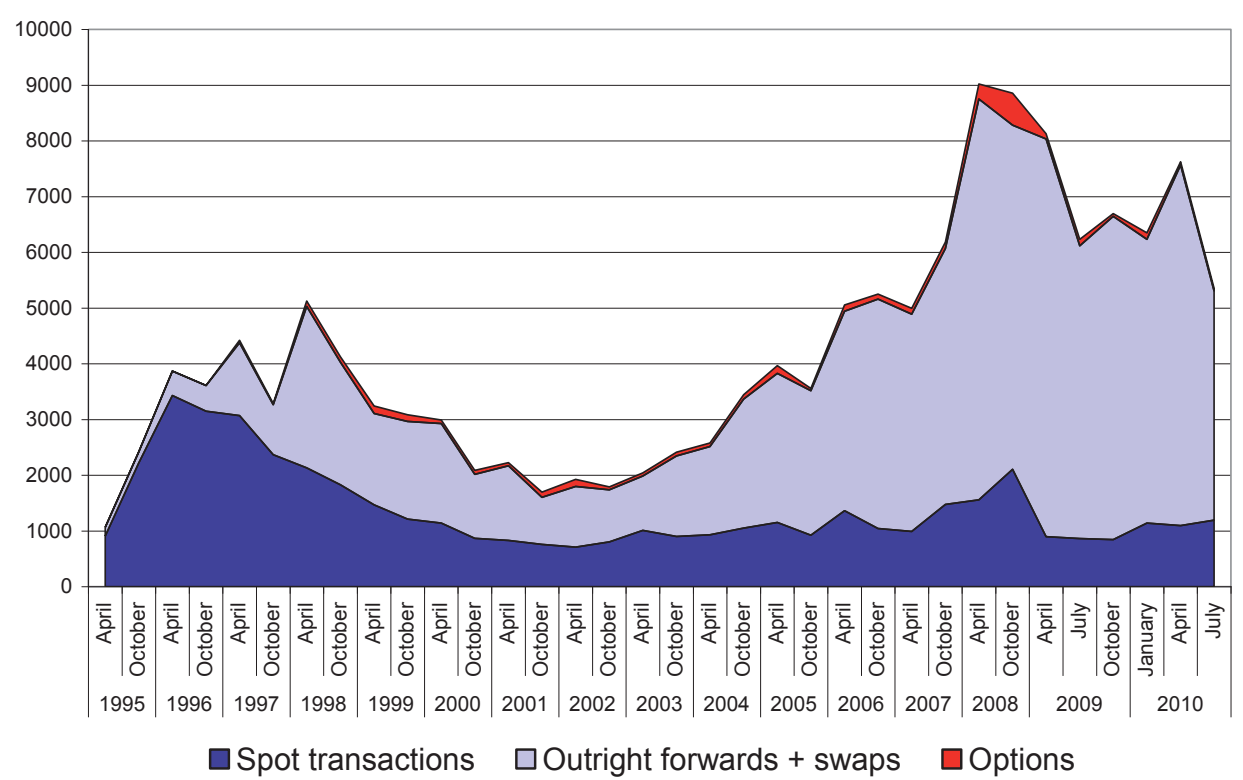

Source: CNB 1995-2010.

The CNB has been publishing data on the average daily turnover on the Czech foreign exchange market since 1995. The total number seen for the period is therefore 32. Since 1998 the information given by the CNB are included in the overview of the development in the foreign exchange turnover on a global scale, the bank issues regularly, at three year intervals, for international payments in Basel. Research always takes one week, and the participants are banks and branches of foreign banks which have banking licenses in the $\mathrm{CR}$, and which are active on the foreign exchange market. The CNB publishes information on the average daily turnover on the foreign exchange markets in aggregate form. Aggregate values arise from the simple total of data from the individual banks, with the exception of the category: "trades with other market makers in the CR", where every trade is reported simultaneously by two participants in the research, and the overall total is, therefore, divided by two. As a first step, we carried out tests on the unit roots with the aid of the augmented Dickey-Fuller test. The results of this test markedly limited our possibilities of testing the original hypothesis because the time rankings for the currency pairing Czech koruna/euro arise out of differing degrees of integration in the individual explanatory vector models (see the information in Table 7). Of the explanatory vectors, the volatility of the spot rate of the Czech koruna/euro is I( 0$)$, the interest differential is I(1), in other words, in cases 
of its absolute values it is even I(2). In the currency pairing of the Czech koruna/ USD, the results of the expanded D-F test give us a better look at the formulated econometric model. Because of the fact that all the time series rankings considered are, in this case, type I(1), we have decided to choose co-integration analysis and Error Correction Model (ECM). The results of our estimates are presented in Table 6. The estimates we carried out of the parameters of the model did not overturn the hypothesis that increased volatility of the spot rates and the growing interest differential lead to the growth of the share of forward and swap transactions in relation to the spot transactions. Somewhat better properties are shown by model (2), with absolute values of the interest differential as explanatory vectors. In model (2), correctional parameter ECM has negative markings, which means that the observed vectors do not mutually diverge, rather, they converge into the state of equilibrium. This finding we consider to be consistent with our hypothesis, because for the turnover on the foreign exchange market it is not important whether the interest differential is positive or negative; what is important is the absolute magnitude.

Table 7

Results of the Unit Root Test (Augmented D-F Test)

\begin{tabular}{|c|c|c|c|c|}
\hline Vector & Symbol & $\begin{array}{l}\text { Degree of } \\
\text { integration }\end{array}$ & t-statistics & $\begin{array}{c}5 \% \\
\text { Significance } \\
\text { level }\end{array}$ \\
\hline Volatility of the spot rate: CZK/EUR & & $\mathrm{I}(0)$ & -4.6591 & -3.6793 \\
\hline Volatility of the spot rate: CZK/USD & $\mathrm{SD}(\mathrm{CZK} / \mathrm{USD})$ & $\mathrm{I}(1)$ & -4.3404 & -2.9862 \\
\hline $\begin{array}{l}\text { Interest differential: } \\
\text { CZK-EUR }\end{array}$ & & $\mathrm{I}(1)$ & -3.4853 & -2.9719 \\
\hline $\begin{array}{l}\text { Interest differential: } \\
\text { CZK-USD }\end{array}$ & IRD(CZK/USD) & $\mathrm{I}(1)$ & -3.9126 & -2.9719 \\
\hline $\begin{array}{l}\text { Interest differential in absolute } \\
\text { values: CZK-EUR }\end{array}$ & & $\mathrm{I}(2)$ & -3.8237 & -2.9981 \\
\hline $\begin{array}{l}\text { Interest differential in absolute } \\
\text { values: CZK-USD }\end{array}$ & $\operatorname{AIRD}(\mathrm{CZK} / \mathrm{USD})$ & $\mathrm{I}(1)$ & -3.8791 & -2.9719 \\
\hline $\begin{array}{l}\text { Relative changes in turnover of spot, } \\
\text { forward, swap and options }\end{array}$ & & $\mathrm{I}(0)$ & -6.3576 & -2.9719 \\
\hline $\begin{array}{l}\text { Relative changes in turnover } \\
\text { of forward, swap and options }\end{array}$ & & $\mathrm{I}(0)$ & -6.9063 & -2.9719 \\
\hline $\begin{array}{l}\text { Relative changes in turnover } \\
\text { of forward and swap }\end{array}$ & & $\mathrm{I}(0)$ & -6.9743 & -2.9719 \\
\hline $\begin{array}{l}\text { Relative changes in turnover } \\
\text { of options }\end{array}$ & & $\mathrm{I}(0)$ & -6.0189 & -2.9919 \\
\hline $\begin{array}{l}\text { Share of turnover } \\
\text { of forward, swap and ptions/spot }\end{array}$ & & $\mathrm{I}(1)$ & -9.9911 & -2.9762 \\
\hline $\begin{array}{l}\text { Share of turnover of forward and } \\
\text { swap/spot }\end{array}$ & RVOL & $\mathrm{I}(1)$ & -10.0201 & -2.9719 \\
\hline $\begin{array}{l}\text { Share of turnover of } \\
\text { options/spot }\end{array}$ & & $\mathrm{I}(0)$ & -3.3378 & -2.9862 \\
\hline
\end{tabular}


Table 8

Results of Co-integration Analysis and Estimates of the Error Correction Model (Johanssen Co-integration Test)

\begin{tabular}{|l|c|c|c|c|c|c|c|}
\hline $\begin{array}{l}\text { Model for } \\
\text { CZK/USD }\end{array}$ & RVOL & SD & IRD & AIRD & ECM & $\begin{array}{c}\text { Amount of } \\
\text { co-integration } \\
\text { vectors }\end{array}$ & Schwarz SC \\
\hline Model (1) & 0.6985 & -1.4191 & -0.0658 & & 0.03 & $1(5 \%)$ & 4.4278 \\
\hline Model (2) & 0.6603 & -1.4977 & & -0.1358 & -0.19 & $1(5 \%)$ & 4.1018 \\
\hline
\end{tabular}

\section{Conclusion}

For the larger number of countries included in the monitored group of 18 (or 13) transitive economies generally, there are no longer frequent changes in the exchange rate regimes that were typical for the 1990s. Most of the countries included in the analysis used the chosen exchange rate regime, either for the entire period under observation, or as the pre-dominant regime. The results of our analysis indicate that transitive countries with fixed foreign exchange rates show, on average, greater stability in exchange rates towards neer because both criteria are in tune with the hypothesis that fixed rates have less of average, both in relative change of exchange rates and in their volatility measured by the standard deviation. The results of our co-integration analysis and Error Correction Model did not overturn the hypothesis that increased volatility of spot rates and a growing interest differential lead to the growth of the share of forward and swap transactions in relation to spot transactions. Our estimates on the example of the Czech foreign exchange market have, thus, confirmed that the increased market risk and higher values of the interest differential lead to the growth of turnover on the foreign exchange market, and that is namely in the area of term foreign exchange transactions (forward, swap and options).

\section{References}

BIS (2004), Triennial Central Bank Survey. Foreign Exchange and Derivatives Market Activity in 2004. BIS, March 2005. ISSN 1814-7356.

BIS (2007), Triennial Central Bank Survey. Foreign Exchange and Derivatives Market Activity in 2007. BIS, December 2007. ISSN 1814-7356.

BIS (2010), Triennial Central Bank Survey. Foreign Exchange and Derivatives Market Activity in 2010. BIS, September 2010. ISSN 1814-7356.

Broz, J. L., Frieden, J., Weymouth, S. (2007), "Exchange Rate Policy Attitude: Direct Evidence from Survey Data." Washington: IMF, 2007.

Brůna, K. (2007), "Měnová politika, změny trendové inflace a nestabilita úrokových relací: Analýza dynamiky dlouhodobých úrokových sazeb v kontextu změn repo sazby České národní banky." (Monetary Policy, Trend Inflation Changes and Volatility of Interest Rates Relations: An Analysis of Long-Term Interest Rate Dynamics in the Context of Changes in Czech National Bank Repo Rate.) Politická ekonomie, 2007, Vol. 55, No. 1, pp. 1-22.

Caramazza, F., Aziz, J. (1998), "Fixed or Flexible? Getting the Exchange Rate Right in the 1990s." Washington: IMF, 1998. 
Crockett, A. D., Goldstein, M. (1976), "Inflation under Fixed and Flexible Exchange Rates." Washington: IMF, 1976.

CNB (2010), Financial Markets. Foreign Exchange Market Information. Prague: CNB, 1995-2010.

Durčáková, J. (2009), "Systémy měnových kurzů, jejich volba v tranzitivních ekonomikách a dopady na vývoj inflace a ekonomického růstu." (Exchange Rate Systems in Transitive Economies and Their Effect on the Development of Inflation and Economic growth.) Politická ekonomie, 2009, Vol.. 57, No. 3, pp. 344-360. ISSN 0032-3233.

Duttagupta, R., Fernandez, G., Karacadag, C. (2005), "Moving to a Flexible Exchange Rate - How, When and How Fast?" Washington: IMF, 2005.

Egstrup, R., Fischer, B. D. (2007), "Foreign Exchange and Derivatives Markets in 2007." Danmarks Nationalbank. Monetary Review. 4th Quarter 2007. http:// www. natioanlbanken.dk/DNUK/ Publications.nsf

Fischer, S. (2001), "Exchange Rate Regimes: Is the Bipolar View Correct?" Finance and Development, 2/2001. http://www.imf.org.

Fleming, J. M. (1975), "Floating Exchange Rates, Asymmetrical Intervention and the Management of International Liquidity." Washington: IMF, 1975.

Frenkel, J., Goldstein, M., Mason, P. (1991), "Characteristics of a Successful Exchange Rate System." Washington: IMF, 1991.

Friedman, M. (1953), "The Case for Flexible Exchange Rates in Essay in Positive Economics." Chicago: University of Chicago Press, 1953.

Gosh, A. R., Ostry, J. D., Gulde, A. M., Wolf, H. C. (1997), "Does the Exchange Rate Regime Matter for Inflation and Growth?" Washington: IMF, 1997.

Habermeier, K., Kokenyne, A., Veyrune, R., Anderson, H. (2009), "Revised System for the Classification of Exchange Rate Arrangements." IMF Working Paper 211. September 2009.

Hlédik, T. (2004), "Quantifying the Second-round Effects of Supply-Side Shocks on Inflation." Prague Economic Papers, 2004, Vol. 13, No. 2, pp. 121-141.

Hoffmann, M. (2007), "Fixed Versus Flexible Exchange Rates: Evidence from Developing Countries." Economica, LSE, 2007, pp. 425-449.

Holub, T. (1999), "Ceny v českém zahraničním obchodě." (Prices in the Czech Foreign Trade), Finance a úvěr. 1999, Vol. 49, No. 5, pp. 253-267.

IMF (1996), IMF World Outlook. Washington: IMF, 1996.

Mandel, M.; Zelenka, V. (2009), "Ztráta centrální banky - účetní a ekonomický pohled." (Central Bank Losses. An Economic and Accounting Perspective Using the Example of the Czech National Bank.) Politická ekonomie. 2009, Vol. 57, No. 6., pp. 723-739.

Mussa, M., Mason, P., Swoboda, A., Jadres E., Mauro P., Berg, A. (2000), “Exchange Rate Regimes in an Increasingly Integrated World Economy." IMF Occasional Paper, Washington, 2000, No. 193.

NBP (2004), Turnover in the Polish Foreign Exchange and OTC Derivatives Markets in April 2004. Result Summary. National Bank of Poland, 2004.

NBP (2007), Turnover in the Polish Foreign Exchange and OTC Derivatives Markets in April 2007. Result Summary. National Bank of Poland, 2007.

Singal, V. (1999), "Floating Currencies, Capital Controls, or Currency Boards: What is the Best for the Currency Crisis." Journal of Applied Corporate Finance. 1999, Vol. 11, No. 4.

Szapary, G. (2001), "Transitive Countries' Choice of Exchange Rate Regime in the Run-Up to EMU." Finance and Development, IMF, 2/2001.

Šaroch, S.; Šindel, J. (2008), "Politická ekonomie kurzové politiky ve střední a východní Evropě odvětvový přistup." (The Political Economy of Exchange Rate Policy). Politická ekonomie. 2008, Vol. 56, No. 1, pp. 17-39.

Williamson, J. (1991), "Advice on the Choice of an Exchange Rate Policy." ICEG Working Paper, May 1991, No. 3. 